\title{
KINERJA KEUANGAN MATAHARI DEPARTMENT STORE Tbk
}

\author{
Danna Solihin \\ University of 17 Agustus 1945 Samarinda \\ Jl. Ir. H. Juanda No. 80, 75124, Indonesia \\ solihindanna@gmail.com
}

\begin{abstract}
The increasing advanced technology developments have changed the pattern of people's lives, including in terms of fulfilling their daily needs. The use of internet media and various online application services has provided a lot of convenience to carry out transactions in the sale and purchase of goods and services. PT Matahari Department Store, which is one of the largest retail companies in Indonesia, has experienced the impact of this change in recent years.

This study aims to analyze the financial performance of PT Matahari Department Store. The data used is secondary data obtained through the financial statements of PT Matahari Department Store which are published on the Indonesia Stock Exchange for the period of 2016-2018.

Based on the analysis of the decline in financial performance for the period 2016 - 2018 which is viewed from the liquidity ratio through the current ratio, solvency ratio through total debt to total asset ratio and profitability ratio through return on assets.
\end{abstract}

Keywords : Financial Performance, Liquidity, Profitability, Solvency

PENDAHULUAN

Dewasa ini perkembangan teknologi semakin pesat. Tidak dapat dipungkiri bahwa hal ini berdampak pula dengan berkembangnya pola pikir dan kebiasaan masyarakat dalam melakukan berbagai aktivitas terutama dalam pemenuhan kebutuhan produk barang dan jasa. Jaringan internet bukan hanya dapat digunakan sebagai alat komunikasi berkirim pesan online namun seiring berkembangnya zaman, jaringan internet dimanfaatkan oleh penyedia layanan untuk mengembangkan bisnis mereka melalui e-commerce yang salah satu bentuknya adalah online shop atau belanja online. Keadaan ini merupakan suatu hal yang lumrah sebab jumlah pengguna internet yang terus mengalami peningkatan dapat menjadi sebuah pasar yang potensial untuk dimasuki para pebisnis dan aktualisasi belanja yang terjadi sangat cepat, nyaman, serta dapat dilakukan di mana saja dan kapan saja. Berbagai macam invosi dilakukan oleh penyedia barang maupun jasa untuk mempromosikan sekaligus 
menggencarkan produk melalui media sosial yang diyakini memiliki pengaruh besar dalam pemasaran produk. Menjamurnya online shop di Indonesia hingga saat ini masih menjadi perbincangan hangat dikalangan masyarakat khususnya anak muda yang identik dengan hal-hal instan tanpa mengeluarkan banyak tenaga dalam pemenuhan kebutuhan.

Belanja online merupakan kegiatan pembelian barang dan jasa melalui media Internet. Belanja online diklasifikasikan sebagai transaksi $e$ commerce Business toConsumer (B2C) (Turban et. al, 2004). Menjamurnya usaha dagang online yang merebak di Indonesia, ditambah kecanggihan teknologi yang menggabungkan platform online dan layanan jasa maupun produk tentu saja mendatangkan banyak keuntungan dan kerugian baik dari pihak produsen, distributor maupun konsumen.

Pada data sensus ekonomi 2016 dari BPS pertumbuhan e-commerce setiap tahunnya berada di kisaran 17 persen dengan total jumlah usaha ecommerce mencapai 26,2 juta unit. Berdasarkan infografis Statista pada tahun 2017, penjualan e-commerce B2C pada tahun 2015 adalah sebesar USD 4,61 miliar meningkat pada tahun 2016 emnjadi USD 5,65 miliar. Angka tersebut diperkirakan akan terus meningkat hingga tahun 2020 sebesar USD 12,39 miliar.

Lembaga survei Nielsen menyebut, faktor utama tutupnya sejumlah gerai departement store berkaitan dengan semakin maraknya toko online (e-commerce). Pasalnya, frekuensi orang berbelanja online paling banyak saat ini untuk kebutuhan fashion yang menjadi barang jualan utama departement store. Matahari Department Store, satu diantara beberapa perusahaan ritel yang mengalami dampak tersebut. Berikut merupakan laba bersih tahun berjalan Matahari Departement Store selama periode 2016-2018:

Tabel 1. Laba tahun berjalan periode $2016-2018$

\begin{tabular}{|c|c|}
\hline Tahun & Laba Tahun Berjalan (Rp) \\
\hline 2018 & 1.097 .332 \\
\hline 2017 & 1.907 .077 \\
\hline 2016 & 2.019 .705 \\
\hline
\end{tabular}

Sumber: www.idx.co.id 
Data tersebut menunjukkan bahwa selama kurun waktu 2016-2018, laba tahun berjalan terus mengalami penurunan yang mengindikasikan terjadinya penurunan kinerja keuangan PT Matahari Departement Store Tbk. Berdasarkan latar belakang tersebut, penulis tertarik untuk menganalisis kinerja keuangan perusahaan tersebut yang ditinjau dari rasio likuiditas dan solvabilitas.

\section{KERANGKA TEORITIS}

\section{Akuntansi Manajemen}

Menurut Chartered Institute of Management Accountants (CIMA), akuntansi manajemen adalah proses identifikasi, pengukuran, akumulasi, analisis, penyusunan, interpretasi, dan komunikasi informasi yang digunakan oleh manajemen untuk merencanakan, mengevaluasi, dan pengendalian dalam suatu entitas dan untuk memastikan sesuai dan akuntabilitas penggunaan sumber daya tersebut. Menurut Hasen dan Mowen (2009) akuntansi manajemen bertanggung jawab mengidentifikasi, mengumpilkan, mengukur, menganalisis, menyiapkan, menginterprestasikan, dan mengomunikasikan informasi yang digunakan oleh manajemen untuk mencapai tujuan dasar
organisasi.Akuntansi manajemen harus menyediakan informasi yang memungkinkan manajer untuk berfokus pada nilai bagi pelanggan, manajemen kualitas total, dan persaingan berdasarkan waktu.

\section{Tujuan Akuntansi Manajemen}

Akuntansi manajemen bertujuan menghasilkan informasi keuangan untuk pihak manajemen. Jenis informasi yang diperlukan berbeda dengan informasi yang diperlukan pihak luar. Umumnya informasi yang dihasilkan bersifat mendalam dan tidak dipublikasikan kepada pihak luar. Tujuan akuntansi manajemen secara umum adalah (Hansen dan Mowen, 2009):

1. Menyediakan informasi yang diperlukan dalam penetuan harga pokok jasa, produk, dan tujuan lain yang diinginkan oleh manajemen.

2. Menyediakan informasi yang digunakan dalam perencanaan, pengendalian, pengevaluasian, dan perbaikan berkelanjutan.

3. Menyediakan informasi untuk pengambilan keputusan. Informasi akuntansi manajemen membantu mengidentifikasi suatu masalah, menyelesaikannya, serta 
mengevaluasi kinerja. Jadi, informasi akuntansi manajemen dibutuhkan dan dipergunakan dalam semua tahapan manajemen, termasuk perencanaan, pengendalian, dan pengambilan keputusan.

\section{Tipe Informasi Akuntansi Manajemen}

Mulyadi (2016) mengemukakan bahwa terdapat 3 tipe informasi di dalam akuntansi manajemen yaitu informasi akuntansi penuh (full accounting information), informasi akuntansi diferensial (diferential accounting information) dan informasi akuntansi pertanggungjawaban (responsibility accounting information).

1. Informasi akuntansi penuh mencakup informasi masa lalu maupun informasi yang akan datang dan mencakup informasi mengenai biaya, pendapatan dan atau aktiva. Informasi akuntansi penuh yang berisi informasi yang akan datang bermanfaat untuk penyusunan program, penetapan harga jual yang diatur dengan peraturan pemerintah.

2. Informasi akuntansi diferensial merupakan taksiran perbedaan aktiva, pendapatan dan atau biaya dalam alternatif tindakan tertentu dibandingkan dengan alternatif tindakan yang lain.

3. Informasi akuntansi pertanggungjawaban merupakan informasi aktiva, pendapatan dan atau biaya yang dihubungkan dengan manajer yang bertanggung jawab atas pusat pertanggungjawaban tertentu yang dibutuhkan dalam proses penyusunan anggaran.

\section{Laporan Keuangan}

Laporan keuangan adalah suatu laporan yang berisikan informasi seputar keuangan dari sebuah organisasi. Laporan keuangan di buat atau diterbitkan oleh perusahaan dari hasil proses akuntansi agar bisa menginformasikan keuangan dengan pihak dalam mapun pihak luar yang terkait. Menurut Fahmi (2012) Laporan keuangan merupakan suatu informasi yang menggambarkan kondisi keuangan suatu perusahaan dan lebih jauh informasi tersebut dapat dijadikan sebagai gambaran kinerja keuangan perusahaan tersebut. Laporan keuangan menurut Sutrisno (2012) hasil akhir dari proses akuntansi yang meliputi dua laporan utama yaitu neraca dan laporan laba rugi.

Berdasarkan beberapa definisi tersebut dapat disimpulkan bahwa 
laporan keuangan merupakan hasil akhir dari proses akuntansi yang dapat memberikan informasi mengenai kondisi keuangan suatu perusahaan dan lebih jauh informasi tersebut dapat dijadikan sebagai gambaran kinerja keuangan perusahaan tersebut.

\section{Tujuan Laporan Keuangan}

Tujuan laporan keuangan yang umum yaitu memberikan informasi mengenai kondisi keuangan perusahaan pada saat tertentu maupun pada periode tertentu. Menurut Kasmir (2009:89) beberapa tujuan pembuatan atau penyusunan laporan keuangan yaitu :

1. Memberikan informasi tentang jenis dan jumlah aktiva yang dimiliki perusahaan pada saat ini.

2. Memberikan informasi tentang jenis dan jumlah kewajiban dan modal yang dimiliki perusahaan saat ini.

3. Memberikan informasi tentang jenis dan jumlah pendapatan yang diperoleh pada suatu periode tertentu.

4. Memberikan informasi tentang jenis dan jumlah biaya yang dikeluarkan perusahaan dalam suatu periode tertentu.

5. Memberikan informasi tentang perubahan-perubahan yang terjadi pada aktiva, pasiva dan modal perusahaan.

6. Memberikan informasi tentang kinerja manajemen perusahaan dalam suatu periode tertentu.

7. Memberikan informasi tentang catatan-catatan atas laporan keuangan.

8. Informasi keuangan lainnya.

Tujuan Laporan Keuangan, menurut Irham Fahmi (2012) yaitu memberikan informasi kepada pihak yang membutuhkan tentang kondisi suatu perusahaan dari sudut angkaangka dalam satuan moneter.

\section{Komponen Laporan Keuangan}

Menurut Tunggal (2009:9) suatu laporan keuangan pada umumnya terdiri dari :

1. Neraca yaitu laporan yang sistematis tentang aktiva, hutang serta modal dari suatu saat tertentu

2. Laporan laba rugi yaitu laporan yang sistematis tentang penghasilan, biaya rugi-laba yang diperoleh suatu perusahaan selama periode tertentu

3. Laporan arus kas yaitu laporan yang memuat informasi sumber dan penggunaan kas perusahaan selama satu periode tertentu

4. Catatan atas laporan keuangan yaitu laporan yang memuat informasi 
tentang dasar penyusunan laporan keuangan, kebijakan akuntansi yang dipilih, diterapkan terhadap peristiwa dan transaksi yang terpenting.

Informasi yang wajib dalam Standar Akuntansi Keuangan (SAK) tetapi tidak disajikan di neraca, laporan laba rugi, laporan arus kas dan laporan perubahan ekuitas. Informasi tambahan yang tidak disajikan dalam laporan keuangan tetapi diperlukan dalam rangka penyajian yang wajar.

\section{Kinerja Keuangan}

Menurut Ikatan Akuntan Indonesia (IAI, 2009) kinerja perusahaan dapat diukur dengan menganalisa dan mengevaluasi laporan keuangan. Informasi posisi keuangan dan kinerja keuangan di masa lalu seringkali digunakan sebagai dasar untuk memprediksi posisi keuangan dan kinerja di masa depan dan hal-hal lain yang langsung menarik perhatian pemakai seperti dividen, upah, pergerakan harga sekuritas dan kemampuan perusahaan untuk memenuhi komitmennya.

Penilaian kinerja setiap perusahaan berbeda-beda karena itu tergantung kepada ruang lingkup bisnis yang dijalankannya. Ada beberapa tahap dalam menganalisis kinerja keuangan suatu perusahaan secara umum (Fahmi, 2012) yaitu melakukan review terhadap data laporan keuangan dengan tujuan agar laporan keuangan yang sudah dibuat tersebut sesuai dengan penerapan kaidah-kaidah yang berlaku umum dalam dunia akuntansi, sehingga dengan demikian hasil laporan keuangan tersebut dapat dipertanggungjawabkan. Melakukan perhitungan yang disesuaikan dengan kondisi dan permasalahan yang sedang dilakukan sehingga hasil dari perhitungan tersebut akan memberikan suatu kesimpulan sesuai dengan analisis yang diinginkan. Melakukan perbandingan terhadap hasil hitungan yang telah diperoleh Metode yang paling umum dipergunakan untuk melakukan perbandingan ini melalui dua teknik yaitu pertama, Time series analysis, yang membandingkan secara antar waktu atau antar periode, dengan tujuan itu nantinya akan terlihat secara grafik, kedua, Cross sectional approach, yaitu melakukan perbandingan terhadap hasil hitungan rasio-rasio yang telah dilakukan antara satu perusahaan dan perusahaan lainnya dalam ruang lingkup yang sejenis yang dilakukan secara bersamaan. Melakukan penafsiran (interpretation) terhadap 
berbagai permasalahan yang ditemukan, untuk melihat apa-apa saja permasalahan dan kendala-kendala yang dialami oleh perbankan tersebut. Mencari dan memberikan pemecahan masalah (solution) terhadap berbagai permasalahan yang ditemukan, guna memberikan suatu input atau masukan agar apa yang menjadi kendala dan hambatan selama ini dapat terselesaikan.

\section{Pengukuran Kinerja Keuangan}

Rasio Likuiditas

Menurut Prastowo (2011) rasio likuditas perusahaan menggambarkan kemampuan perusahaan dalam memenuhi kewajiban jangka pendeknya kepada kreditor jangka pendek. Rasio likuiditas adalah rasio yang menunjukkan kemampuan perusahaan dalam memenuhi kewajiban atau membayar utang jangka pendeknya. Untuk mengukur kemampuan perusahaan dalam menyelesaikan kewajiban jangka pendeknya, ada beberapa rasio yang dapat dipergunakan yaitu :

1. Current ratio merupakan rasio untuk mengukur kemampuan perusahaan dalam memenuhi kewajiban jangka pendeknya yang segera jatuh tempo dengan menggunakan aset lancar yang tersedia.

2. Quick ratio yaitu rasio yang digunakan untuk mengukur kemampuan perusahaan dalam memenuhi atau membayar kewajiban atau utang lancar (utang jangka pendek) dengan aktiva lancar tanpa memperhitungkan nilai persesediaan (inventory).

3. Cash ratio merupakan alat yang digunakan untuk mengukur seberapa besar uang kas yang tersedia untuk membayar utang.

Rasio Solvabilitas

Menurut Prastowo (2011) rasio solvabilitas adalah rasio yang menunjukkan kemampuan perusahaan dalam memenuhi segala kewajibannya baik jangka pendek maupun jangka panjang apabila perusahaan dilikuidasi. Rasio yang dipergunakan yaitu :

1. Total debt to total asset ratio yaitu rasio yang digunakan untuk mengukur prosentase besarnya dana yang berasal dari hutang. Rasio ini menunjukkan sejauh mana hutang dapat ditutupi oleh aktiva.

2. Total debt to total equity ratio yaitu suatu rasio keuangan yang menunjukkan proporsi relatif antara 
ekuitas dan hutang yang digunakan untuk membiayai aset perusahaan.

Rasio Profitabilitas

Menurut Prastowo (2011) rasio yang digunakan untuk mengukur kemampuan suatu perusahaan dalam mendapatkan laba. Rasio yang dipergunakan yaitu

1. Net profit margin yaitu rasio yang digunakan untuk mengukur rupiah laba bersih yang dihasilkan oleh setiap satu rupiah penjualan dan mengukur seluruh efisien, baik produksi, administrasi, pemasaran, pendanaan,penentuan harga maupun manajemen pajak.

2. Return on Asset yaitu rasio yang digunakan untuk melihat sejauh mana investasi yang telah ditanamkan mampu memberikan pengembalian keuntungan sesuai dengan yang diharapkan.

\section{METODE PENELITIAN}

Metode penelitian yang digunakan dalam penelitian ini adalah metode penelitian deskriptif. Penelitian dilakukan pada PT Matahari Department Store Tbk yaitu satu diantara beberapa perusahaan yang terdaftar di Bursa Efek Indonesia. Data yang digunakan yaitu laporan keuangan yang dipublikasi oleh PT Matahari
Department Store Tbk periode 20162018. Rasio yang digunakan untuk mengukur kinerja keuangan dalam penelitian ini yaitu:

1. Current ratio $=\frac{\text { Aktiva Lancar }}{\text { Kewajiban Lancar }}$ Semakin besar perbandingan aktiva lancar dengan kewajiban lancar semakin tinggi kemampuan perusahaan menutupi kewajiban jangka pendeknya.

2. Quick ratio $=$ $\frac{\text { Aktiva Lancar-Persediaan }}{\text { Kewajiban Lancar }}$

Semakin tinggi Quick Ratio suatu perusahaan, semakin baik posisi keuangan perusahaan tersebut.

3. Total Debt to Total Asset ratio = $\frac{\text { Total Kewajiban }}{\text { Total Aktiva }}$

Semakin kecil rasionya semakin aman (solvable)

4. Return On Asset $=\frac{\text { Laba Bersih }}{\text { Total Aktiva }}$ Semakin tinggi return on assets, maka semakin baik total aktiva yang dipergunakan untuk operasi perusahaan mampu memberikan laba bagi perusahaan sehingga kondisi ini efisien bagi perusahaan.

ANALISIS DAN PEMBAHASAN

Analisis 
Dalam melakukan analisis kinerja keuangan, peneliti melakukan perhitungan terhadap beberapa rasio keuangan diantaranya current ratio, quick ratio, return on asset dan total debt to total asset.

Tabel 2. Perhitungan Rasio Keuangan PT Matahari Department Store Tbk

\begin{tabular}{|c|c|c|c|c|}
\hline Keterangan & Current Ratio & Quick Ratio & Return On Asset & Total Debt to Total Asset \\
\hline 2018 & 1,10 & 0,62 & 0,21 & 0,63 \\
\hline 2017 & 1,13 & 0,75 & 0,35 & 0,57 \\
\hline 2016 & 1,14 & 0,76 & 0,41 & 0,61 \\
\hline
\end{tabular}

Sumber: data diolah, 2019

Berdasarkan data yang ditunjukkan pada tabel 2, terlihat bahwa kinerja keuangan PT Matahari Department Store Tbk terus mengalami penurunan. Ditinjau dari aspek rasio likuiditas, pada tahun 2018 terjadi penurunan kinerja keuangan yang ditunjukkan oleh penurunan sebesar 3,40\% dibandingkan tahun sebelumnya untuk current ratio dan penurunan sebesar 16,54 \% dibandingkan tahun sebelumnya untuk quick ratio. Sedangkan di tahun 2017 terjadi penurunan sebesar $0,87 \%$ dibandingkan tahun sebelumnya untuk current ratio dan penurunan sebesar 1,39\% dibandingkan tahun sebelumnya untuk quick ratio. Sama halnya apabila ditinjau dari aspek profitabilitas, terjadi penurunan kinerja keuangan yang diperlihatkan oleh rasio return on asset. Pada tahun 2018 mengalami penurunan sebesar $38 \%$ dibandingkan tahun sebelumnya dan pada tahun 2017 mengalami penurunan sebesar $14,77 \%$ dibandingkan tahun sebelumnya. Namun jika ditinjau dari aspek solvabilitas yang diukur melalui rasio total debt to total asset, kinerja keuangan perusahaan tersebut mengalami fluktuatif. Pada tahun 2018 mengalami penurunan kinerja sebesar $11,98 \%$ dibandingkan tahun sebelumnya, sedangkan di tahun 2017 mengalami peningkatan kinerja sebesar 6,86\% dibandingkan tahun sebelumnya.

\section{Pembahasan}

Berdasarkan hasil analisis terjadi penurunan kinerja keuangan pada PT Matahari Department Store Tbk periode 2016-2018. Penurunan ini disebabkan terjadinya peningkatan total kewajiban, beban pokok pendapatan, beban usaha dan penurunan laba tahun berjalan serta penurunan nilai investasi. Selanjutnya jika dilihat dari aspek global, terjadinya pergeseran tren bisnis dan gaya hidup masyarakat juga merupakan satu diantara beberapa hal penyebab turunnya laba PT. Matahari Department 
Store. Sebagian besar masyarakat terutama generasi muda cenderung lebih senang melakukan transaksi menggunakan aplikasi berbasis online dibandingkan datang ke toko-toko offline kerena lebih efektif dan efisien.

\section{KESIMPULAN}

Berdasarkan hasil penelitian menunjukkan bahwa kinerja keuangan PT Matahari Department Store Tbk mengalami penurunan pada periode 2016-2018 ditinjau dari aspek likuiditas melalui current ratio dan quick ratio, aspek profitabilitas melalui return on asset ratio dan aspek solvabilitas melalui total debt to total asset ratio.

\section{SARAN}

Bagi perusahaan sebaiknya terus meningkatkan ekspansi toko-toko mereka dengan berbasis online dalam rangka meningkatkan pertumbuhan penjualan guna memenuhi kebutuhan pasar dan mengikuti perkembangan gaya hidup masyarakat saat ini. Bagi peneliti selanjutnya sebaiknya dapat melanjutkan penelitian ini dengan menggunakan rasio-rasio keuangan lainnya seperti cash ratio, total debt to total equity ratio, net profit margin dan sebagainya.

\section{DAFTAR PUSTAKA}

Fahmi, Irham. 2012. Analisis Laporan

Keuangan, Cetakan Ke-2.

Alfabeta:

Bandung.

Hansen dan Mowen. 2009. Akuntansi Manajemen, Edisi 8. Salemba Empat: Jakarta.

Harahap, Sofyan Syafri. 2008. Analisis Kritis atas Laporan Keuangan. Raja Grafindo Persada: Jakarta.

Kasmir. 2009. Analisis Laporan Keuangan. Rajawali Pers: Jakarta.

Mamduh M. Hanafi dan Abdul Halim. 2012. Analisis Laporan Keuangan, Cetakan Kedua. UPP STIM YKPN: Yogyakarta.

Mulyadi. 2016. Sistem Akuntansi. Salemba Empat: Jakarta

Prastowo, Dwi. 2011. Analisis Laporan Keuangan Konsep dan Aplikasi. Edisi Ketiga, Cetakan Pertama. UPP STIM YKPN: Yogyakarta.

Raharjaputra, Hendra S. 2011. Buku Panduan Praktis Manajemen Keuangan dan Akuntansi untuk Eksekutif Perusahaan. Salemba Empat: Jakarta.

Sjahrial, Dermawan. 2009. Pengantar Manajemen Keuangan. Mitra Wacana Media: Jakarta

Sutrisno. 2012. Manajemen Keuangan: Teori Aplikasi \& Konsep. Ekonisia: Yogyakarta. 